\title{
Le Simplegadi
}

Rivista internazionale on-line di lingue e letterature moderne International refereed online journal of modern languages and literatures

http://all.uniud.it/simplegadi

ISSN 1824-5226

\section{Narrating Empathy: \\ Story-Telling and Equitable Inter-Connections in Languages and Literatures}

Anno XVII, Numero 19

Novembre 2019 


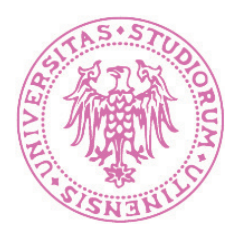

\section{Le Simplegadi \\ http://all.uniud.it/simplegadi}

Rivista accademica on-line dell'Associazione dei Laureati in Lingue Straniere dell'Università di Udine

International refereed online journal of modern languages and literatures

Direttore responsabile / Editor-in-chief: Antonella Riem

Segretario di redazione / Editor: Stefano Mercanti

\section{Comitato scientifico / Scientific Board:}

Satish C. Aikant (H. N. B. Garhwal University, India)

Roberto Albarea (University of Udine, Italy)

Paolo Bartoloni (University of Galway, Ireland)

Paolo Bertinetti (University of Turin, Italy)

Maria Bortoluzzi (University of Udine, Italy)

Veronica Brady $(\dagger)$ (University of Western Australia, Australia)

Alessandra Burelli (University of Udine, Italy)

Maria Luisa Camaiora (University "Cattolica" Milan, Italy)

Silvia Caporale Bizzini (University of Alicante, Spain)

Franca Cavagnoli (University of Milan, Italy)

Saumitra Chakravarty (Bangalore University, India)

Andrea Csillaghy (University of Udine, Italy)

Anna Pia De Luca (University of Udine, Italy)

Maria Renata Dolce (University of Salento, Italy)

Cynthia vanden Driesen (Edith Cowan University, Australia)

Riane Eisler (Center for Partnership Studies, USA)

Alessandra Ferraro (University of Udine, Italy)

Armando Gnisci $(\dagger)$ (University “La Sapienza” Rome, Italy)

Alessandro Grossato (University of Trento, Italy)

Linda Hutcheon (University of Toronto, Canada)

Michael Hutcheon (University of Toronto, Canada)

Paul Kane (Vassar College, USA)

Mark Klemens (Independent scholar, USA)

Renata Londero (University of Udine, Italy)

Claudio Melchior (University of Udine, Italy)

Richard Nile (Murdoch University, Australia)

Annalisa Oboe (University of Padua, Italy)

Nduka Otiono (Carleton University, Canada)

Federica Pedriali (University of Edinburgh, UK)

Deborah Saidero (University of Udine, Italy)

Andrew Taylor (Edith Cowan University, Australia)

John Thieme (University of East Anglia, UK)

Itala Vivan (University of Milan, Italy) 
Comitato di redazione / Editorial Board:

Direttore responsabile / Editor-in-chief: Antonella Riem antonella.riem@uniud.it

Segretario di redazione / Editor: Stefano Mercanti stefano.mercanti@uniud.it

Redazione: Caterina Colomba, Simona Corso, Maria Paola Guarducci, Maria Maddalena

Lorubbio, Lidia De Michelis, Alessandro Romanin, Loredana Salis, Roberta Trapè.

E-mail: simplegadi@uniud.it

\section{Sede amministrativa / Address:}

Dipartimento di Lingue e letterature, comunicazione, formazione e società

Palazzo Antonini, via Petracco, 8

33100 Udine

Italia

Tel: 0432556778

\section{(cc) EY}

The articles of this issue are licensed under a Creative Commons Attribution 3.0 unported license available at http:// creativecommons.org/licenses/by/3.0/

This license allows you to share, copy, distribute and transmit the work; to adapt the work and to make commercial use of the work. The work must be attributed to the respective authors (but not in any way that suggests that they endorse you or your use of the work).

Autorizzazione del Tribunale di Udine N. 2 del 5 marzo 2003

ISSN 1824-5226

Indirizzo Direttore responsabile / Address of Editor-in-Chief:

Prof. Antonella Riem Natale

Dipartimento di Lingue e letterature, comunicazione, formazione e società

Palazzo Antonini, via Petracco, 8

33100 Udine, Italia

e-mail: antonella.riem@uniud.it

tel. 0432556773

E-mail: simplegadi@uniud.it

Rivista Annuale - Pubblicazione del numero in corso: 30 novembre 2019

Issued on 30th November 2019

Rivista accademica fascia 'A' - Anvur

Refereed ' $A$ ' ranked journal

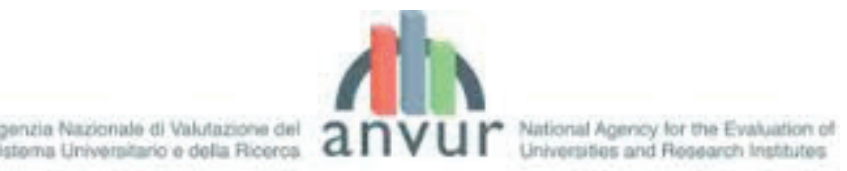




\author{
Narrating Empathy: \\ Story-Telling and Equitable Inter-Connections \\ in Languages and Literatures \\ edited by Antonella Riem and Stefano Mercanti \\ Le Simplegadi \\ Anno XVII, Numero 19, Novembre / November 2019 \\ http://all.uniud.it/simplegadi - ISSN 1824-5226
}

\title{
POETICHE / POETICS
}

Riane Eisler. Not to Worry, Not to Be Unduly Concerned

Le Simplegadi, 2019, XVII, 19: 7-17

Chris Mann. Scapegoat

Le Simplegadi, 2019, XVII, 19: 18-19

Marco Fazzini. Speaking Out: Lawrence Ferlinghetti@100

Le Simplegadi, 2019, XVII, 19: 20-29

Mehmet Yashin. Les paroles d'un autre

Le Simplegadi, 2019, XVII, 19: 30

Andrew Greig. Poems

Le Simplegadi, 2019, XVII, 19: 31-33

Giovanni Nimis. Il coraggio di amare tra realtà e fiction

Le Simplegadi, 2019, XVII, 19: 34-42

\section{ARTICOLI / ARTICLES}

Biancamaria Rizzardi. “Once Upon a Time” by Nadine Gordimer: A Fairy Tale for Peace Le Simplegadi, 2019, XVII, 19: 43-52

Angela Locatelli. Plurivocal Narration as an Empathetic Response of Resistance to Colonial Prejudice. Writing Alterity in The Voyage Out

Le Simplegadi, 2019, XVII, 19: 53-64

Héliane Ventura. Empathy and Irony in "Keeping Fit" by Nadine Gordimer Le Simplegadi, 2019, XVII, 19: 65-72 
Maria Renata Dolce. 'Her-stories' per una cultura di pace: Indigo, La tempesta al femminile di Marina Warner tra passato e futuro

Le Simplegadi, 2019, XVII, 19: 73-88

Laura Colombino. 'To Inhabit in Tranquility': Landscape, Vision and Empathy in Ford Madox Ford's No Enemy

Le Simplegadi, 2019, XVII, 19: 89-100

Fabiana Fusco. Feminicide in the Italian Language: Which Words to Describe Gender-based Violence?

Le Simplegadi, 2019, XVII, 19: 101-118

Francesca Di Blasio. We Are Going by Oodgeroo Noonuccal. Aboriginal Epos, Australian History, Universal Poetry

Le Simplegadi, 2019, XVII, 19: 119-127

Maria Micaela Coppola. The Quest for Insight and Empathy in Alice Munro's Stories of Dementia

Le Simplegadi, 2019, XVII, 19: 128-138

Pia Masiero, Laura Tosi. The (Difficult) Rehabilitation of the Fairy-tale Villain

Le Simplegadi, 2019, XVII, 19: 139-152

Claudia Gualtieri. Vivere con la razza nei racconti di Elleke Boehmer

Le Simplegadi, 2019, XVII, 19: 153-166

Roberta Trapè. Building Empathy and Intercultural Citizenship through a Virtual Exchange Project

Le Simplegadi, 2019, XVII, 19: 167-180

Nickolas Komninos. Narratives and Critical Literacy in Health Websites for Children

Le Simplegadi, 2019, XVII, 19: 181-205

Angelo Monaco. Narrative Empathy in James Bradley's Clade: Disability, Ecosickness and Hope

Le Simplegadi, 2019, XVII, 19: 206-217

Martina Zamparo. "Albion beheld thy beauty". Vala, Jerusalem and Blake's Holistic Approach to the Cosmos

Le Simplegadi, 2019, XVII, 19: 218-236

Eleonora Natalia Ravizza. Jhumpa Lahiri's Narratives of Self-Translation as Dynamic Encounters with the Other

Le Simplegadi, 2019, XVII, 19: 237-246 
Ilaria Boato, Giorgia Salvador. Risorse e ambienti digitali per l'apprendimento linguistico autonomo e tra pari

Le Simplegadi, 2019, XVII, 19: 247-260

\section{RECENSIONI / REVIEWS}

Coral Ann Howells. Nurturing Our Humanity: How Domination and Partnership Shape Our Brains, Lives, and Future

Le Simplegadi, 2019, XVII, 19: 261-263

Marco D'Agostini. Jill Mellick's The Red Book Hours: A Creative Dialogue with Carl Gustav Jung's Work

Le Simplegadi, 2019, XVII, 19: 264-273

Serena Guarracino. I sensi del testo. Scrittura, riscrittura e traduzione (Giuseppe Sofo)

Le Simplegadi, 2019, XVII, 19: 274-276

Elisa Forlin. Rassegna bibliografica: didattica innovativa per l'insegnamento delle letterature di lingua inglese nella scuola secondaria di secondo grado

Le Simplegadi, 2019, XVII, 19: 277-282

Amit Shankar Saha. Not in My Name: Selected Poems 1978-2017 (Subodh Sarkar)

Le Simplegadi, 2019, XVII, 19: 283-288 


\title{
Francesca Di Blasio
}

\section{We Are Going by Oodgeroo Noonuccal. Aboriginal Epos, Australian History, Universal Poetry*}

\begin{abstract}
I: We Are Going di Oodgeroo Noonuccal esce per Jacaranda Press nel 1964 ed è la prima raccolta di poesie con autorialità aborigena mai pubblicata. Il testo è interpretabile sia come epos aborigeno che come documento di storia australiana, e in esso le storie dei singoli individui si intrecciano dolorosamente con la macrostoria delle politiche egemoniche bianche nei confronti degli indigeni. L'elaborazione poetica del recente passato traumatico, collettivo e soggettivo, diventa una forma di superamento del trauma stesso grazie all'evocazione di un passato molto più antico, quello della cultura indigena precedente all'invasione. Il seguente lavoro analizza le poesie di Oodgeroo in questa prospettiva, tenendo presente la loro specificità come testi artistici, letterari e poetici. L'esperienza di tradurre We Are Going per la sua prima edizione italiana (Oodgeroo 2013) è stata una via privilegiata di avvicinamento al testo e ai suoi significati.
\end{abstract}

Abstract II: The first collection of poetry by an Aboriginal author, Oodgeroo Noonuccal, was published in 1964 by Jacaranda Press. We Are Going embodies key features of Aboriginal literature and can be interpreted as an Aboriginal epos as well as a document in Australian history. Individual stories often painfully interface with the macro-history of white policies towards Indigenous people. This poetical remembering of a recent and traumatic past becomes a form of recovery from trauma itself, since Oodgeroo's poetics preserve the memory of a much older past, the one of pre-invasion Indigenous culture. This paper aims at analysing Oodgeroo's poems in this perspective, by focussing on both their epical and historical features, while keeping in mind their specificity as artistic, literary, and poetic texts. The experience of translating We Are Going for its first Italian edition (Oodgeroo 2013) has been greatly instrumental in coming to terms with the richness and significance of the poems.

In 1964, a collection of poetry written by an Aboriginal author, We Are Going by Oodgeroo Noonuccal (1964), was published by Jacaranda Press, under the auspices of a foresightful Judith Wright. Oodgeroo (1920-1993) was both the first Aboriginal woman, and the first Aboriginal poet, to publish a book of verse. At the time, Oodgeroo's name was Kath Walker,

* This paper was awarded the ANDA Prize for the best “Unpublished Critical Essay" in September 2018. 
and We Are Going proved to be a great commercial success, breaking the Great Australian Silence on the Indigenous question. Walker was an activist for Aboriginal rights and land rights, and her artistic production, spanning the period from the 1960s to the 1990s ${ }^{1}$, was always intertwined with political issues. It is protest poetry, and undoubtedly a form of 'literature of identity'.

Oodgeroo's poetry is part of a process that makes memory alive through writing, and projects that very memory into the future. Her texts echo the ancient 'fables of identity', as they could be defined in a Western perspective, and act as border-crossings and hybrid forms of writing (Di Blasio 2005, 2013b, 2016); they sustain the potential of the future to unfold, through representations of the past. These poems of dispossession and reorientation interrogate the style of the dominant (and domineering) white establishment (Mitchell 1987) and pose, among many others, the following pressing questions: What does it mean to be a foreigner in one's own land? How can an identity suspended between past and present be re-articulated? Will artistic creativity dare to give voice to this suspended identity, and thus shape prospective changes? These texts also raise challenges for the future, since they invite discussion of seminal issues, such as: the need to preserve cultures that are under the threat of disappearance; the meaning of 'minor' literature and culture in the Deleuzean sense of the term (Deleuze \& Guattari 1996); confrontation with forms of 'otherness'; the preservation or transformation of individual cultures in multicultural societies (Kohn \& McBride 2011), social and cultural hybridisation.

Oodgeroo's collection is a form of memory in many ways. It often weaves in hegemonic and official Australian history, and individual stories interface, usually in a painful way, with the macro-history of white policies towards Indigenous people (Di Blasio 2018)2. Alongside this form of memory, centered on a recent, traumatic past, and also a form of recovery from trauma itself, Oodgeroo's poems preserve the memory of an older past, the past of pre-invasion Indigenous culture (Assmann 2006). This pre-colonial memory, which can be defined as 'epic' memory, has been severely compromised by colonial policies, and yet it still survives, giving shape to the Indigenous Weltanschauung in many ways. A special dialectic originates in this to and fro movement between past and present: the remembrance of the past stimulates a searching attitude towards the future, and vice versa, in a dynamic relationship between memory and longing (Di Blasio 2009), beautifully expounded in the central poem that gives the title to the collection, a text which we come to and analyse in the pages that follow.

Oodgeroo's poems will be explored from a critical perspective focused on their epical and historical features, bearing in mind their specificity as artistic, literary, and poetic writings. The experience of translating We Are Going for its first Italian edition ${ }^{3}$ (Di Blasio \& Zanoletti 2013b) has been one important mode of access to the text. The intimate and 'calligraphic', i.e. minutely detailed experience of translating a text from one language to anoth-

\footnotetext{
${ }^{1}$ See also Oodgeroo/Walker 1966, 1988 and 1990.

2 On the relation between literature, history, and cultural memory see: Hayden White (1987, 2010), Paul Ricoeur (2000), Catherine Gallagher \& Stephen Greenblatt (2000), Angela Locatelli (2010).

3 All poems are quoted from this edition.
} 
er, and of making it accessible from one culture to another, has proven extremely productive for a deeper understanding of this seminal collection. The need to deal with every single word articulating a world of trauma has been a complex and precious task for the translator. The many important issues to be faced related to struggle, recovery, protest, hope, political positioning, reinvented and regenerated identity, cultural memory, epos, negotiation, resilience, a foreshadowing of the future and a reconstruction of the past. To translate has meant to know, to know again, to know better, and of course also to share, with new readers and with students, the beauty of Oodgeroo's poetry and the value of the cultural memory which is part and parcel of it.

The poems analysed here are mostly concerned with the recollection of a far away cultural past, which is made alive again precisely by being evoked in and through poetry. The selection of less overtly political texts, in which a lyrical tone prevails, illustrates in a very effective way the power of literature to represent its subjects in an empathetic ${ }^{4}$, and emotionally involving way, which is able to provide readers with a special and effective form of knowledge ${ }^{5}$.

The first poem to be discussed is Then and Now, which is built around the dialectic movement between past and present outlined above:

1 In my dreams I hear my tribe

2 Laughing as they hunt and swim,

3 But dreams are shuttered by rushing car,

4 By grinding tram and hissing train,

5 And I see no more my tribe of old

6 As I walk alone in the teeming town.

1 I have seen corroboree

2 Where that factory belches smoke;

3 Here where they have memorial park

4 One time old lubras dug for yams;

5 One time our dark children played

6 There where the railway yards are now,

7 And where I remember the didgeridoo

8 Calling to us to dance and play,

${ }^{4}$ On literature and empathy in the Australian context see Riem (2017). On literature and emotions see also Carroll \& Gibson (2011).

5 The history of the critical reception of Oodgeroo's poetry is highly controversial. When the book was published, several critics belittled Oodgeroo's poems, judging them as "impoetic" (see, for example, the reviews by Andrew Taylor for the Australian Book Review, and by Leon Cantrell for Poetry Magazine). The political significance of Oodgeroo's poetry is recognised as a value beginning with the readings of Roberta Sykes and Colin Johnson/Mudrooroo Narogin. In order to define this kind of poetry, the latter coined the term "poetemics", which fuses the idea of poetry with that of political denunciation (poetics and polemics). In more recent times, Adam Shoemaker (2004) points out again how the value of Oodgeroo's poetry resides precisely in its being political, and politically passionate. Here, the readability of these texts as "poetry" is highlighted. 
9 Offices now, neon lights now,

10 Bank and shop and advertisement now,

11 Traffic and trade of the busy town.

12 No more woomera, no more boomerang,

13 No more playabout, no more the old ways.

14 Children of nature we were then,

15 No clocks hurrying crowds to toil.

16 Now I am civilized and work in the white way,

17 Now I have dress, now I have shoes:

18 "Isn't she lucky to have a good job!"

19 Better when I had only a dillybag.

20 Better when I had nothing but happiness (Oodgeroo 2013: 202).

At first glance, the theme of loss seems central to this poem, since the happy, almost edenic recollections of the past sharply collide with the representation of an industrialised and alienating present. A series of images in the poem provides the reconstruction of a whole world and of a specific lebensform which is evoked in: the tribe (1. 1), the corroboree (1. 7), the didgeridoo (1.13). These symbolic objects speak of the life of a community destroyed by white 'civilisation', but writing makes that very life present and clearly desired, because still dreamt of (1. 1), albeit not visible, given the interfering presence of the "offices" and "neon lights" (1.15), and not audible, given the hissing of the train and the rushing of the car (11. 3-4). This narrative strategy of memory is even more evident in the preterition that opens the last stanza of the poem (11. 18-19), which emphasises the use of Aboriginal words, or words in Aboriginal English: "corroborree" (1. 7), "lubras" (1. 10), "didgeridoo" (1. 13), "woomera", "boomerang" (1. 18), "playabout" (1. 19), "dillybag" (1. 25), disclosing a whole world (Brathwaite 1995). In fact, what we have here is a mimesis of re-creation in absence, and the derogatory connotations of the signs of white presence which run throughout the poem increase the sense of longing for another past, as well as for another future.

It is worth noticing that the word "dream", used in the first stanza, is not a neutral term in Indigenous culture and in Aboriginal English. In its sketchy and undifferentiated version it could be considered a 'white invention'; still, the very word "Dreamtime" is often appropriated and refunctionalised in Indigenous literature as a mark of identity. Although the meaning of this loaded term has often undergone a process of oversimplification imposed by the homogenizing Western view on Aboriginal culture, a culture which is far from being a univocal reality, this mythical past of Creation, the time evoked by traditional stories, is often present in Oodgeroo's production. In Indigenous contemporary literature, traditional stories are usually not explicitly mentioned, or openly told, either because most of them belong to a given community, or because they are a sacred form of knowledge which requires belonging in order to be communicated and received. It is in the corroborees, i.e. in the sacred ceremonies, that they can be narrated to the community itself, as people from the outside are not permitted to participate or watch.

A sense of this exclusion of all alien gaze animates the following poem, which depicts the scene of a corroboree, as anticipated by its very title: 


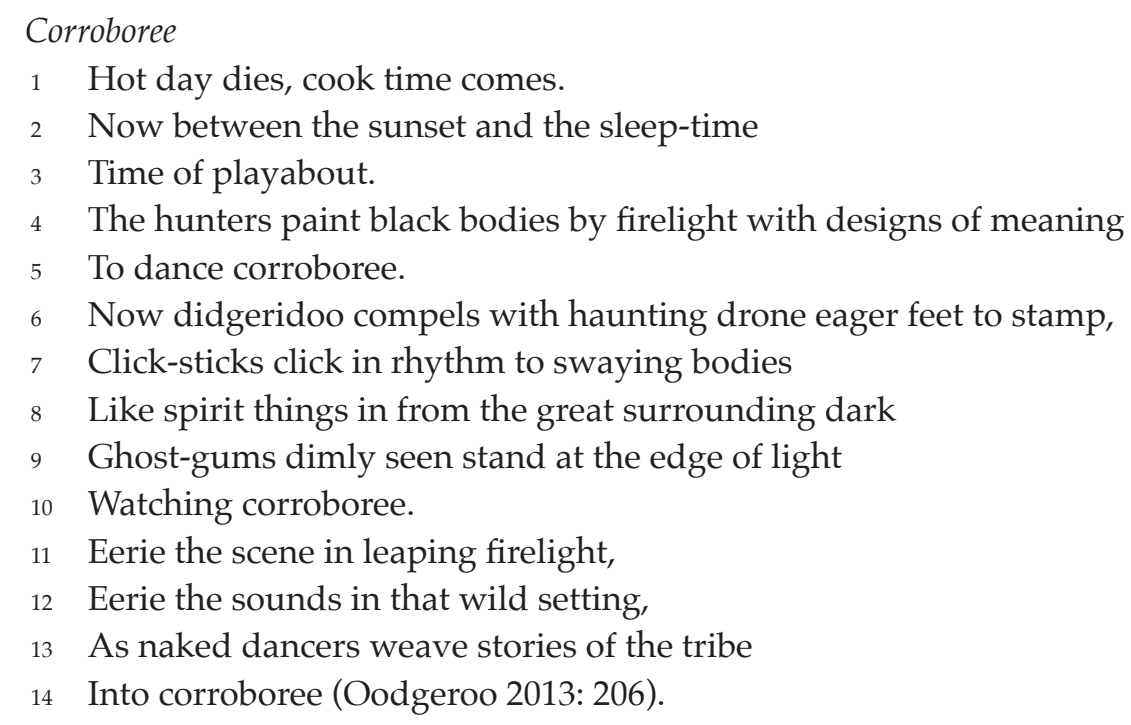

The nocturnal setting of the poem enhances the sense of mystery of the whole scene for the reader, while, in contrast, the protagonists experience progressively stronger involvement in the ceremonial event, as emphasised at the end of each stanza. The use of epistrophe creates a climax in the chronological sequence, starting with the planning of the ceremony (11. 3-4) and ending with full participation in it (1. 15). Narration itself acquires a strong physical connotation (which re-actualises the sense of storytelling in Aboriginal oral literature) ${ }^{6}$ through the image of the "designs of meaning" (1. 4) depicted on the dancers' naked bodies as they "weave" the stories of the tribe (1. 13). Reticence to disclose the actual content of these stories enhances the potential of their significance by opening up the interpretive process in different directions. Since the "common reader" is forbidden to know these stories directly, her curiosity is tickled and s/ he is led to explore a variety of different hypotheses regarding their nature, plots and topics. This strategy sustains another form of desire: the desire for interpretation, fuelled, in this case, mostly by memory and its literary forms.

In the eponymous We Are Going, different chronological levels merge in the use of the present tense while the narrative itself concentrates on a past life. This rhetorical strategy climaxes in the striking assertion of line 14, "we are the past". The speaking voice in the poem identifies with the past, and suggests that it can recreate that past in the present, albeit temporarily:

1 They came into the little town

2 A semi-naked band subdued and silent,

3 All that remained of their tribe.

4 They came here to the place of their old bora ground

5 Where now the many white men hurry about like ants.

6 Notice of estate agent reads: "Rubbish May Be Tipped Here".

6 On the relation between literature and orality see Carlson, Fagan \& Khanenko (2011). 
7 Now it half covers the traces of the old bora ring.

8 They sit and are confused, they cannot say their thoughts:

9 "We are as strangers here now, but the white tribe are the strangers.

10 We belong here, we are of the old ways.

11 We are the corroboree and the bora ground,

12 We are the old sacred ceremonies, the laws of the elders.

13 We are the wonder tales of Dream Time, the tribal legends told.

14 We are the past, the hunts and the laughing games, the wandering camp fire.

15 We are the lightning-bolt over Gaphembah Hill

16 Quick and terrible,

17 And the Thunder after him, that loud fellow.

18 We are the quiet daybreak paling the dark lagoon.

19 We are the shadow-ghosts creeping back as the camp fires burn low.

20 We are nature and the past, all the old ways

21 Gone now and scattered.

22 The scrubs are gone, the hunting and the laughter.

23 The eagle is gone, the emu and the kangaroo are gone from this place.

24 The bora ring is gone.

25 The corroboree is gone.

26 And we are going (Oodgeroo 2013: 224).

Anaphora ("We are" 11. 10-20) obsessively reaffirms a remembered communal identity; isocolon reinforces the centrality of the parallels between past and present, humans and landscape. However, in the closing line the progressive verbal form, "we are going", implies a twofold meaning: both permanence and annihilation, resilience and destruction. It is an ambivalent concluding line, one that can turn upside down the commonsensical significance of the poem, if taken merely as a celebration of identity. "We are going" here may in fact refer to the progressive ending of a culture and of a community ("we are disappearing together with 'all the old ways', the 'scrubs' and 'animals'"), but it may also refer to the sense of a movement onwards: "we are moving further, we keep on moving towards the future against all odds". The last line recaptures the anaphoric structure of the poem, and in so doing it seems to recover a sense of identity precisely from the previous assertions and their recollection of a long gone past. Memory guarantees continuity in absence. In evoking the past, the symbolic connotations of the images are always at work, for example in the mythical, circular time thematized in the central part of the poem. It is a time that runs from daybreak (1.18) up to the nighttime camp fires (1.19) and it makes up one whole day, naturally (1. 20) calling for another.

A subtle interplay of memory and projection into the future is to be found in Dawn Wail for the Dead, a poem of nostalgic commemoration, a dirge (11. 5-11), but also a text thematising the need to build a new beginning (11. 12-14) on the verge of an ending (1.12), and isotopically referring to both the end of the ritual and the end of the poem itself:

1 Dim light of daybreak now

2 Faintly over the sleeping camp. 
3 Old lubra first to wake remembers:

4 First thing every dawn

5 Remember the dead, cry for them.

6 Softly at first her wail begins,

7 One by one as they wake and hear

8 Join in the cry, and the whole camp

9 Wails for the dead, the poor dead

10 Gone from here to the Dark Place:

11 They are remembered.

12 Then it is over, life now,

3 Fires lit, laughter now,

14 And a new day calling (Oodgeroo 2013: 226).

Mourning is the theme of this poem, but from the collective remembrance and celebration of the dead, a cathartic epic song originates, a song that is able to heal and regenerate, and to give hope for the future, for the "new day calling" (1. 14).

In a subsequent collection entitled The Dawn is at Hand, published in 1966, the poem The Past reads:

1 Let no one say the past is dead.

2 The past is all about us and within.

3 Haunted by tribal memories, I know

4 This little now, this accidental present

5 Is not all of me, whose long making

6 Is so much of the past.

7 Tonight here in Suburbia as I sit

8 In easy chair before electric heater,

9 Warmed by the red glow, I fall into dream:

10 I am away

11 At the camp fire in the bush, among

12 My own people, sitting on the ground.

13 No walls about me,

14 The stars over me,

15 The tall surrounding trees that stir in the wind

16 Making their own music.

17 Soft cries of the night coming to us, there

18 Where we are one with all old Nature's lives

19 Known and unknown,

20 In scenes where we belong but have now forsaken.

21 Deep chair and electric radiator

22 Are but since yesterday.

23 But a thousand thousand camp fires in the forest

24 Are in my blood. 
25 Let none tell me the past is wholly gone.

26 Now is so small a part of time, so small a part

27 Of all the race years that have moulded me (Oodgeroo/Walker 1966: 45).

Oodgeroo's lyrical voice is peremptorily clear in the opening section of the poem, summoning the readers to share a vision of a past which is not, by any means, gone for good. In these very intense opening lines, it is the present that has to be questioned and circumscribed to a "little now" (1. 4). The present is just a 'splinter of time' compared to the much longer process of past ages, continually forging the poet's identity from a tenaciously persisting past. This process is ongoing and the past still gives shape to the subject and her relation to a complex form of both individual and cultural memory.

The poem goes on, describing the poet in her current, urbanised context. The apparently cozy atmosphere of an intimate, domestic scene heated by an electric radiator soon expands into the dream of unextinguished camp fires and of a communal life which still gives full substance to the poet's contemporary identity.

The past articulated in this and in many other poems has the power of inhabiting the present. This is its main feature: it is a 'progressive past' (Di Blasio 2013a), in the positive sense in which a cultural rebirth is made possible after the traumatic experience of material and spiritual expropriation. Oodgeroo's past is not nostalgically sentimental, rather, it is a living and pulsing source constantly regenerating Indigenous existence.

\section{BIBLIOGRAPHY}

Assmann, Aleida. 2006. Memory, Individual and Collective. Robert E. Goodin \& Charles Tilly eds. The Oxford Handbook of Contextual Political Analysis. Oxford: Oxford University Press, 210-224.

Brathwaite, Edward Kamau. 1995. Nation Language. B. Ashcroft, G. Griffiths \& H. Tiffin eds. The Postcolonial Studies Reader. London: Routledge, 309-313.

Carlson, Keith T., Kristina Fagan \& Natalia Khanenko-Friesen eds. 2011. Orality and Literature: Reflections Across Disciplines. Toronto: University of Toronto Press.

Carroll, Noël \& John Gibson eds. 2011. Narrative, Emotion, and Insight. University Park (PA): The Pennsylvania State University Press.

Deleuze, Gilles e Félix Guattari. 1996. Kafka. Per una letteratura minore. Macerata: Quodlibet. Di Blasio, Francesca e Margherita Zanoletti. 2013. Oodgeroo Noonuccal, con We Are Going/E noi andiamo. Trento: Editrice Università degli Studi di Trento, Collana Labirinti.

Di Blasio, Francesca. 2005. The Pelican and the Wintamarra Tree: voci della letteratura aborigena australiana. Trento: Editrice Università degli Studi di Trento, Collana Labirinti.

Di Blasio, Francesca. 2009. Memory is Desire: Epistemological Premises and Desiring Textualities in Indigenous Australian Literature. Textus, 23, 1: 270-298.

Di Blasio, Francesca. 2013a. Passato progressivo: "Written On Paperbark".

Di Blasio, Francesca. 2013b. La disseminazione del margine: leggere la letteratura australiana delle donne. Mercedes Arriaga Flórez, Salvatore Bartolotta \& Milagro Martín Clavijo eds. Ausencias: escritoras en los márgenes de la cultura. Sevilla: ArCiBel, 348-365. 
Di Blasio, Francesca. 2016. "I am born of the conquerors, you of the persecuted": la Storia s/velata nella poesia di Judith Wright e Oodgeroo Noonuccal. Daniele Cerrato ed. Desde los margenes: narraciones y representaciones femininas. Sevilla: Benilde Ediciones, 43-54.

Di Blasio, Francesca. 2018. "Pretty deadly tidda business": la Storia in una vita, la vita in una storia. Rita Huggins e Jackie Huggins. [1994]. Auntie Rita, Introduzione. Francesca Di Blasio (traduzione e a cura di). Prefazione di Jackie Huggins. Verona: Delmiglio, 9-37.

Gallagher, Catherine \& Stephen Greenblatt. 2000. Practicing New Historicism. Chicago: University of Chicago Press.

Kohn, Margaret \& Keally McBride. 2011. Political Theories of Decolonization: Postcolonialism and the Problem of Foundations. Oxford: Oxford University Press.

Locatelli, Angela ed. 2010. La conoscenza della letteratura/The Knowledge of Literature, Vol. 9. Bergamo: Bergamo University Press, Edizioni Sestante.

Mitchell, Susan. 1987. The Matriarchs: Twelve Australian Women Talk About Their Lives to Susan Mitchell. Ringwood (Vic.): Penguin Australia.

Oodgeroo Noonuccal/Kath Walker. 1964. We Are Going. Brisbane: The Jacaranda Press.

Oodgeroo Noonuccal/Kath Walker. 1964. We Are Going: Poems. Brisbane: The Jacaranda Press.

Oodgeroo Noonuccal/Kath Walker. 1966. The Dawn is at Hand: Poems. Brisbane: The Jacaranda Press.

Oodgeroo Noonuccal. 1988. Kath Walker in China. Milton (Qld.): The Jacaranda Press.

Oodgeroo Noonuccal. 1990. My People. Milton (Qld.): The Jacaranda Press.

Oodgeroo Noonuccal/Kath Walker. 2013. We Are Going/E noi andiamo. Francesca Di Blasio e Margherita Zanoletti. Oodgeroo Noonuccal, con We Are Going/E noi andiamo. Trento: Editrice Università degli Studi di Trento, Collana Labirinti.

Ricoeur, Paul. 2000. La mémoire, l'histoire, l'oubli. Paris: Seuil.

Riem, Antonella. 2017. A Gesture of Reconciliation Partnership Studies in Australian Literature. Udine: Forum.

Shoemaker, Adam. 2004. Black Words White Page: Aboriginal Literature 1929-1988. Canberra: Australian National University E Press.

White, Hayden. 1987. The Content of Form: Narrative Discourse and Historical Representation. Baltimore: Johns Hopkins University Press.

White, Hayden. 2010. The Fiction of Narrative: Essays on History, Literature, and Theory. Baltimore: Johns Hopkins University Press.

Francesca Di Blasio, PhD in English literature, teaches at the University of Trento. Her areas of research are Literary Theory, Indigenous Australian Literature, Early Modern Literature, Modernism. She has published articles on George Orwell, Virginia Woolf, Samuel Beckett, Shakespeare, and a volume on the theories of the gaze in English literature (Teoria e Pratiche dello Sguardo, Bergamo 2001). Di Blasio has been working for over a decade, and is still working, on Australian Aboriginal literature and the postcolonial gaze, and on this topic she is the author of various articles, translations and books. She is the president of the Italian Association of Studies on Australia and Oceania (www.aisao.it).

francesca.diblasio@unitn.it 